\title{
Modification of strut effectiveness factor for reinforced concrete deep beams strengthened with CFRP laminates
}

\author{
M. Panjehpour ${ }^{a} \bowtie$, A.A.A. Ali ${ }^{a}$, Y.L. Voo ${ }^{b}$, F.N. Aznieta ${ }^{a}$ \\ a. University Putra Malaysia, (Serdang, Selangor, Malaysia) \\ b. DURA Technology (Sdn Bhd, Ipoh, Malaysia) \\ $\triangle$ mdpanjehpour2006@yahoo.com
}

Received 18 April 2013

Accepted 24 October 2013

Available on line 30 May 2014

\begin{abstract}
This paper proposes a method to modify the strut effectiveness factor in the strut-and-tie model for CFRP-strengthened reinforced concrete deep beams. Two groups of deep beams comprising six ordinary reinforced concrete deep beams and six CFRP-strengthened reinforced concrete deep beams were experimentally tested under the four-point bending configuration. The shear span-to-effective depth ratio of the beams in each group was $0.75,1.00,1.25,1.50,1.75$, and 2.00 . The theoretical principal tensile strain in CFRP-strengthened struts was modified based on a proposed empirical relationship, based on two ratios: the experimental to the theoretical value of principal tensile strain and the shear span-to-effective depth of deep beams.
\end{abstract}

KEYWORDS: Deep beam; Strut effective strength; CFRP; Shear; Strut-and-tie model

Citation / Citar como: Panjehpour, M.; Ali, A.A.A.; Voo, Y.L.; Aznieta, F.N. (2014). Modification of strut effectiveness factor for reinforced concrete deep beams strengthened with CFRP laminates Mater. Construcc. 64 [314], e016. http://dx.doi.org/10.3989/mc.2014.02913.

RESUMEN: Modificación del factor de eficacia de las bielas en vigas de canto de hormigón reforzadas con laminados de polímero reforzado con fibras de carbono. En este trabajo se propone un método en el que se modifica el factor de eficacia que se aplica a las bielas en el modelo de bielas y tirantes para vigas de canto de hormigón reforzadas con laminados CFRP (polímero reforzado con fibras de carbono). Mediante el ensayo a cuatro puntos se determina la resistencia a flexotracción de doce vigas de canto divididas en dos grupos de seis, las del primer grupo de hormigón armado normal y las del segundo de hormigón reforzado con laminados de CFRP. En ambos grupos cada una de las seis vigas se caracteriza por una relación luz de cortante-canto útil distinta, con valores utilizados de: $0.75,1.00,1.25,1.50,1.75$, y 2.00. El valor teórico de la deformación principal por tracción de la biela reforzada con CFRP se modifica de acuerdo con la relación empírica propuesta en este trabajo. Esta se establece a partir de otras dos: la relación entre los valores experimental y teórico de la deformación por tracción principal y la relación luz de cortante-canto útil de las vigas de canto.

PALABRAS CLAVE: Viga de canto; Resistencia efectiva de la biela; CFRP; Cortante; Modelo de bielas y tirantes

Copyright: (C) 2014 CSIC. This is an open-access article distributed under the terms of the Creative Commons Attribution-Non Commercial (by-nc) Spain 3.0 License.

\section{INTRODUCTION}

According to ACI 318-11, a deep beam has a clear span less than or equal to four times the overall depth. Regions with concentrated loads spanning twice the member depth from the support are also considered deep beams (1). Deep beams are commonly utilized in tall buildings, offshore structures, and foundations (2). Deep beams typically function as a transfer girder in a single-span or continuous beam (3).

The strengthening of concrete structures with carbon fiber-reinforced polymer (CFRP) has become a topic of interest among researchers in the 
last decade because CRFP is lightweight and corrosion resistant. CFRPs are easy to install and have high tensile strength, making these materials a useful tool for strengthening concrete structures.

Numerous studies explored the effects of CFRP in three forms (sheet, plate, and bar) on the behavior of RC beams (4-8). Besides, many studies have been conducted to investigate the behavior and capacity of reinforced concrete (RC) beams strengthened with CFRP in terms of flexure $(9,10)$ and shear (11-19). Scant research has been conducted on the shear strength of RC deep beams (20-22) and no attempt has been made to improve the STM to analyze CFRP-strengthened RC deep beams.

Several equations and models to predict concrete-CFRP bond strength (23-28) are in place. The Lorenzis and Miller equation (29), based on a shear lag approach and a simple shear model was used here (Equation [1]).

$$
\tau=0.0184 \sqrt{t . E}
$$

According to various codes and standards, the strut-and-tie model (STM) is a rational approach to analyze deep beams $(30,1,31-36)$. The strut in STM has three common shapes, namely, prismatic, bottle shaped, and fan shaped. The crushing strength of concrete strut in STM is evaluated based on the strut effectiveness factor $(v)$. Available codes and standards are classified into two groups depending on the method utilized to calculate the strut effectiveness factor. The first group comprises AASHTO LRFD, CSA-S6-06, CSA A23.3, and AS 3600, which define the strut effectiveness factor as a function of the principal tensile strain on the strut $(30,31,33,34)$. Originally, the strut effectiveness factor proposed by Vecchio and Collins utilized modified compressivefield (MCF) theory (37). The second group comprises ACI 318-11, DIN 1045-1, NZS 3101, and model code 2010, which recommend a value for the strut effectiveness factor $(1,32,35,36)$.

Equations [2] and [3] are provided by AASHTO for the calculation of the strut effectiveness factor. The equations are based essentially on research conducted on MCF theory (37). This study proposed the stress-strain relationship for cracked concrete during compression as follows:

$$
\varepsilon_{1}=\varepsilon_{s}+\left(\varepsilon_{s}+0.002\right) \cos ^{2}(\theta)
$$

(AASHTO LRFD eq. 5.6.3.3.3-2)

$$
f_{c u}=\frac{f^{\prime}{ }_{c}}{0.8+170 \varepsilon_{1}}<0.85 f^{\prime}{ }_{c}
$$

(AASHTO LRFD eq. 5.6.3.3.3-1)
The strut effectiveness factor can be calculated as follows from Equation [3].

$$
v=\frac{1}{0.8+170 \varepsilon_{1}}<0.85
$$

According to AASHTO LRFD, Es is calculated as below.

$$
\varepsilon_{\mathrm{s}}=\frac{\mathrm{f}_{\mathrm{y}}}{2 \mathrm{E}_{\mathrm{s}}}
$$

The average principal tensile stress for cracked concrete in concrete struts in tension proposed in the above research is presented in Equation [5].

$$
f_{c 1}=\frac{f_{c r}}{1+\sqrt{200 \varepsilon_{1}}}
$$

The use of CFRP sheets to strengthen concrete structural elements continues to increase worldwide. Despite the wide application of STM in structural member design $(38,39)$, the current STM is incapable of predicting the shear strength of CFRPstrengthened deep beams. Hence, the ultimate strength of CFRP-strengthened deep beams is evaluated in the present study to develop a rational model. While numerous studies have been run on STM from various angles (40-47), no research has been conducted on STM where the D-region is strengthened with CFRP, particularly in deep beams. Thus, the main purpose of the present study is to

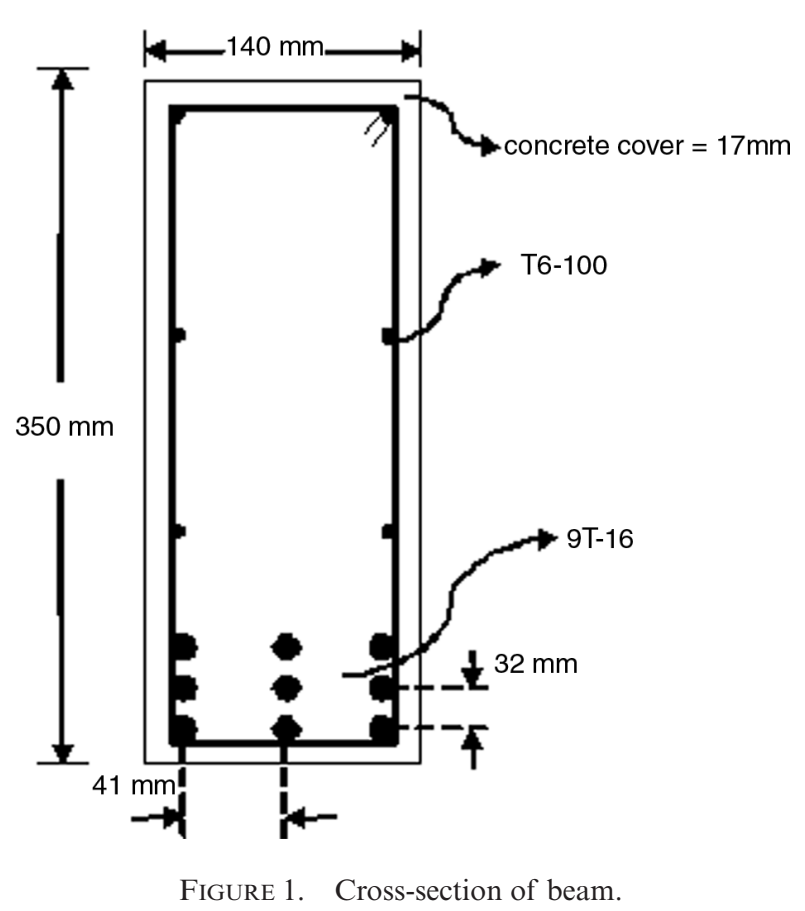




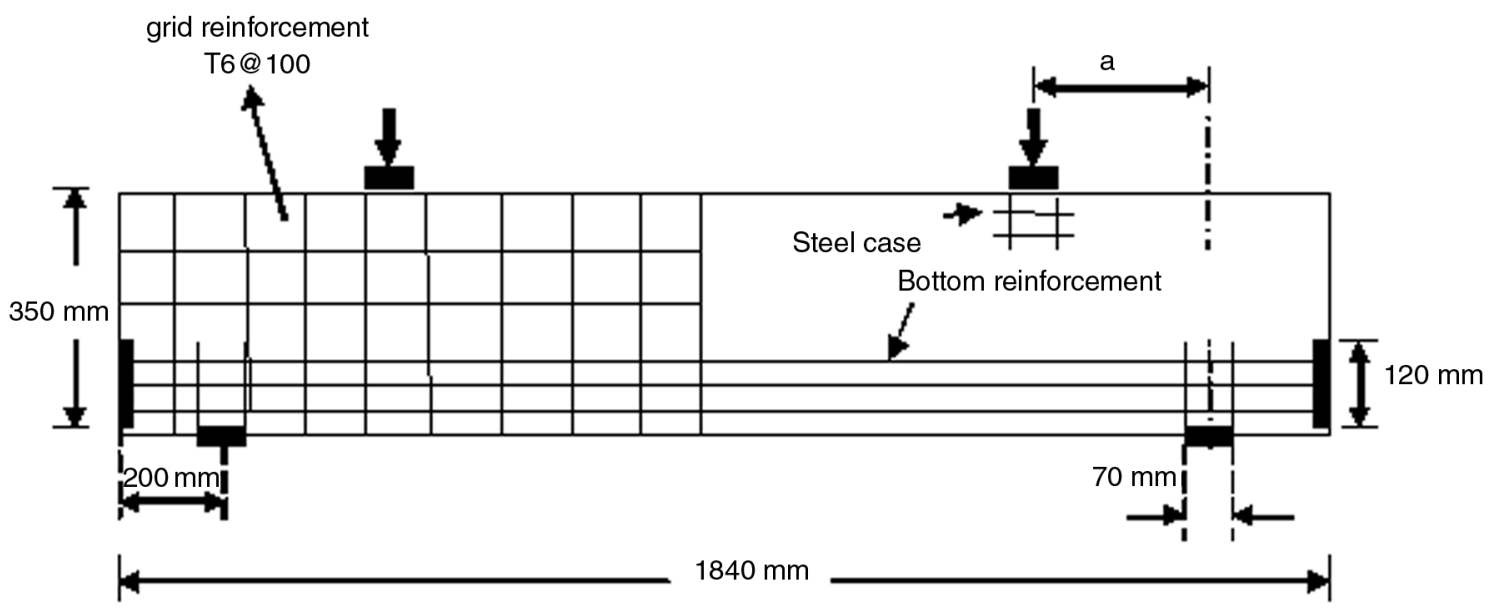

FIGURE 2. Typical reinforcement.

develop the STM for predicting the shear strength of RC deep beams strengthened with CFRP. This study proposes a modified strut effectiveness factor for STM based on an empirical relationship in CFRP-strengthened deep beams. No study has yet been performed to calibrate the value of the principal strain on struts in D-regions to obtain the strut effectiveness factor in STM. The present proposal is to modify the value of principal tensile strain in CFRP-strengthened strut based on an empirical relationship. This study is confined to ordinary reinforced concrete deep beams strengthened with one layer of CFRP sheet applied using wet-lay techniques.

\section{METHODOLOGY}

The reinforced concrete deep beams consisted of two groups: ordinary and CFRP-strengthened deep beams. Each group comprised six deep beams with shear span to effective depth ratios of $0.75,1.00$, $1.25,1.50,1.75$, and 2.00 . CFRP sheets are usually installed on two or three sides, or fully wrapped around the beam. Anchorage is achieved with the three-side and full-wrap systems. Two-sided installation is more common in strengthening, retrofitting, and even repair because of its ease of installation and cost-effectiveness compared to the other two installation systems. This study was therefore confined to two-sided CFRP installation, for it aims to investigate the effect of installing a CFRP sheet without anchorage on the tensile strength of an inclined RC strut. The effect of CFRP anchorage in three-sided and fully-wrapped CFRP installation systems should be explored in future research.

\subsection{Details of deep beams}

The $140 \mathrm{~mm} \times 350 \mathrm{~mm}$ deep beams were essentially identical; they measured $1840 \mathrm{~mm}$.

long and had a rectangular cross section, as illustrated in Figure 1. The flexural reinforcement consisted of nine 16-mm diameter deformed steel bars placed in three layers. The steel bars were welded to 10 -mm thick steel plates at both ends of the beams to provide adequate anchorage. The $120-\mathrm{mm}$ high anchorage steel plates fully covered the width of the beams. The longitudinal bars should be anchored as in standard practice using development length or embedded length. However, the end steel plates were utilized in the experiment to provide additional anchorage because of laboratory size limitations. Steel mesh reinforcement with a mesh size of $100 \mathrm{~mm}$ was provided as transverse reinforcement. The mesh satisfied the required minimum amount of web reinforcement and the recommended maximum spacing of orthogonal grid reinforcement $(300 \mathrm{~mm})$ specified by ACI $318-11$ and AASHTO LRFD $(30,1)$. To prevent premature local failure, additional steel reinforcements were provided under the load plates and on top of the support plates as illustrated in Figure 2. The orthogonal grid reinforcement, used along the length of the beams, is shown only on one side of the beam in Figure 2.

TABLE 1. Typical properties of CFRP sheets and epoxy

\begin{tabular}{lccccc}
\hline Materials & $\begin{array}{c}\text { Tensile strength } \\
(\mathbf{M P a})\end{array}$ & $\begin{array}{c}\text { Tensile modulus of } \\
\text { elasticity }(\mathbf{G P a})\end{array}$ & Elongation at failure & Bond strength $(\mathbf{M P a})$ & Thickness $(\boldsymbol{m m} / \mathbf{p l y})$ \\
\hline CFRP sheet & 3900 & 230 & $1.5 \%\left(7\right.$ days at $\left.+23{ }^{\circ} \mathrm{C}\right)$ & - & 0.111 \\
Epoxy resin & 30 & 4.5 & $0.9 \%\left(7\right.$ days at $\left.+23{ }^{\circ} \mathrm{C}\right)$ & $>4$ & - \\
\hline
\end{tabular}




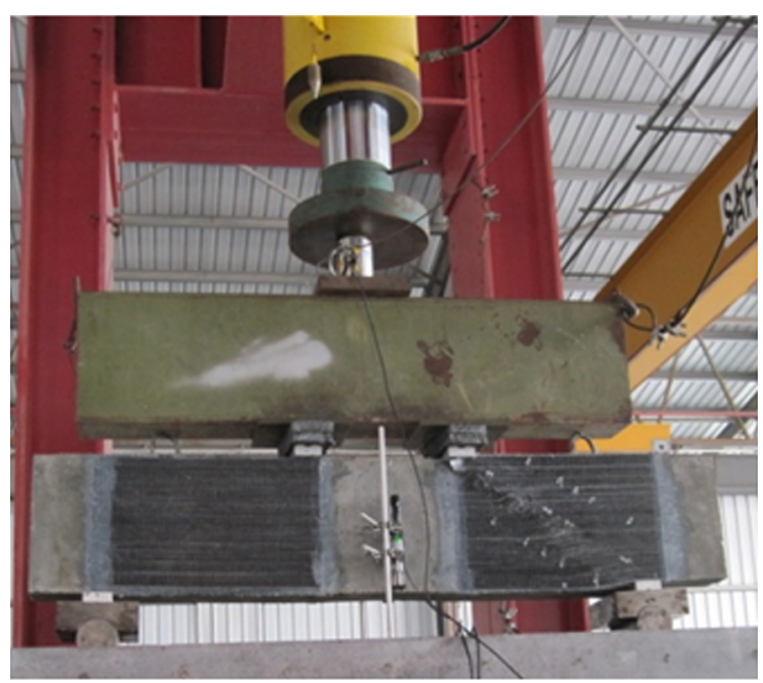

Figure 3. Experimental test set up.

\subsection{Materials and methods}

The beams were cast with a single supply of readymixed concrete. One layer of uni-directionally woven carbon-fiber fabric with a thickness of $0.111 \mathrm{~mm} / \mathrm{ply}$ was wet-laid on the deep beams with a two-part epoxy resin. The direction of the fiber in the installed CFRP sheet was vertical. Table 1 lists the typical properties of the CFRP sheet and epoxy resin provided by the manufacturer. Both the CFRP sheet and epoxy resin were supplied by Sika Company with Sikadur-330 and Sikawrap-230 product data sheets. Strengthening with the CFRP sheet was performed only on the surface of the beams between the load and support plate to cover the shear span of the deep beams. The CFRP-strengthening was cured for at least two days at ambient temperature following the manufacturer's recommendation. The support and load plates, which are $70 \mathrm{~mm}$ wide and $10 \mathrm{~mm}$ thick, fully covered the bottom and top of the beam. The deep beams were tested $28 \mathrm{~d}$ after casting.

TABLE 2. Empirical values for the ultimate shear strength of deep beams and respective mid-span deflection

\begin{tabular}{lcccc}
\hline $\mathbf{a} / \mathbf{d}$ & $\begin{array}{c}\mathbf{P}_{\text {u-ordinary }} \\
(\boldsymbol{k N})\end{array}$ & $\begin{array}{c}\mathbf{P}_{\text {u-FRP }} \\
(\boldsymbol{k N})\end{array}$ & $\begin{array}{c}\boldsymbol{\Delta}_{\text {ordinary }} \\
(\mathbf{m m})\end{array}$ & $\begin{array}{c}\boldsymbol{\Delta}_{\text {CFRP }} \\
\text { strengthening }\end{array}$ \\
\hline 0.75 & 756.95 & 905.31 & 3.29 & 3.99 \\
1.00 & 709.01 & 857.89 & 3.40 & 4.13 \\
1.25 & 604.08 & 740.02 & 3.54 & 4.53 \\
1.50 & 555.91 & 691.04 & 3.59 & 4.66 \\
1.75 & 403.02 & 510.01 & 3.64 & 5.00 \\
2.00 & 360.02 & 468.05 & 3.74 & 5.17 \\
\hline
\end{tabular}

TABLE 3. Ultimate shear strength of deep beams

\begin{tabular}{lccc}
\hline $\boldsymbol{a l d}$ & $\boldsymbol{P}_{\text {u-ordinary-test }}(\boldsymbol{k} \boldsymbol{N})$ & $\boldsymbol{P}_{\text {u-FRP-test }}(\boldsymbol{k} \boldsymbol{N})$ & $\boldsymbol{I R}(\boldsymbol{\%})$ \\
\hline 0.75 & 756.95 & 905.31 & 19.60 \\
1.00 & 709.01 & 857.89 & 21.00 \\
1.25 & 604.08 & 740.02 & 22.51 \\
1.50 & 555.91 & 691.04 & 24.31 \\
1.75 & 403.02 & 510.01 & 26.55 \\
2.00 & 360.02 & 468.05 & 30.02 \\
\hline
\end{tabular}

A universal tensile strength testing machine was used to measure the tensile strength of steel bars. Three samples were chosen from each size of steel bars and the average taken as the final tensile strength. The test was carried out according to standard ASTM-E8 with a strain rate of $0.005 \mathrm{in} / \mathrm{in} / \mathrm{min}$ to measure the ultimate tensile strength of the bars. The tensile strength of the reinforcing steel bars determined as described (T16) was $440 \mathrm{MPa}$, while the compressive and splitting tensile strengths of concrete were 37.02 and $3.31 \mathrm{MPa}$, respectively.

\subsection{Test procedures and instruments}

The beams were tested to failure with a four-point bending configuration. The load was increased to failure with a $5000-\mathrm{kN}$ hydraulic actuator. The load increment was $25 \mathrm{kN}$ during the loading process. The positions of the DEMEC discs were carefully drawn on the surface of the D-regions of the beams. The DEMEC discs were then properly positioned on the beam surface using a DEMEC invar bar at 200-mm intervals. DEMEC disc spacing was accurately measured in each step of loading since the DEMEC resolution was $0.001 \mathrm{~mm}$. As the ultimate shear strength of CFRP-strengthened RC deep beams was not predictable, the DEMEC measurement process for all beams was continued following the load increment steps of $25 \mathrm{kN}$ till the beams failed. Figure 3 shows the experimental test set-up with the DEMEC discs positioned along and perpendicular to the strut centerline. The strain perpendicular to the strut centerline at mid-height of the beam section was the focus of calculation in this study.

\section{EXPERIMENTAL RESULTS AND DISCUSSION}

The results were carefully measured using calibrated tools since there only one test was available for each a/d ratio in this study. This section presents the relationship between the shear strength of CFRP deep beams and the shear span-to-effective depth ratio with a view to modifying the STM for 


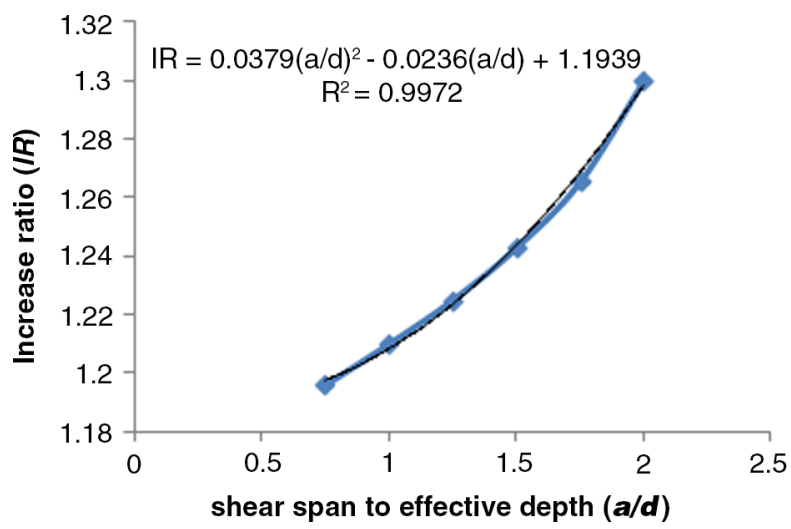

FIGURE 4. Empirical relationship for predicting the shear strength of CFRP-strengthened deep beams.

CFRP-strengthened deep beams. Then, an empirical relationship was established to modify the value of the strut effectiveness factor of the CFRPstrengthened deep beams.

\subsection{Failure of deep beams}

According to the experimental observation, the tendency of having brittle failure perceptibly increases among the ordinary RC deep beams as the shear span to the effective depth ratio decreases. Nonetheless, the foregoing tendency was observed to be weaker in CFRP-strengthened RC deep beams than in ordinary RC deep beams. The ultimate shear strength of ordinary RC deep beams and CFRP-strengthened deep beams and their respective mid-span deflection values are shown in Table 2. According to Table 2 , the mid-span deflection of ordinary and CFRPstrengthened RC deep beams corresponding to the ultimate load slightly increased with the shear spanto-effective depth ratio.

However, the ductility and energy absorption of ordinary and CFRP-strengthened RC deep beams should be explored in further research. The partial rupturing of the CFRP sheet was the dominant failure mode in the two-sided CFRP-strengthened deep

TABLE 4. Calculation of the modification ratio based on $\varepsilon_{1-F R P}$ and $\varepsilon_{1-F R P-t e s t}$

\begin{tabular}{lccc}
\hline ald & $\boldsymbol{\varepsilon}_{\mathbf{1 - F R P} \times 10^{-4}}$ & $\boldsymbol{\varepsilon}_{\mathbf{1 - F R P - t e s t}} \times \mathbf{1 0 ^ { - 4 }}$ & $\boldsymbol{R}$ \\
\hline 0.75 & 4.85 & 25.87 & 5.33 \\
1.00 & 6.50 & 35.25 & 5.41 \\
1.25 & 8.27 & 64.29 & 7.77 \\
1.50 & 10.07 & 84.33 & 8.37 \\
1.75 & 11.86 & 142.97 & 12.05 \\
2.00 & 13.60 & 169.82 & 12.48 \\
\hline
\end{tabular}

beams in this experiment. In other words, only part of the beam section failed without CFRP sheet rupture, while the failure of the remaining beam section occurred simultaneously and involved rupture of the CFRP sheet.

\subsection{Ultimate shear strength of deep beams strengthened with CFRP}

Among the studies conducted on deep beams hitherto, no attention has been paid to CFRP strengthening of deep beams with various shear span-to-effective depth ratios. Table 3 shows the ultimate shear strength of ordinary and CFRPstrengthened deep beams based on the experimental results of this study. The last column in Table 3 shows the increase in ultimate shear strength of deep beams bearing CFRP sheets. Two crucial trends were observed from the experimental results. First, as the shear span-to-effective depth ratio (a/d) increased, the ultimate shear strength of the ordinary and CFRP-strengthened deep beams decreases. This trend is consistent with the findings of previous studies $(2,47)$. Second, the shear strength of the CFRP-strengthened deep beams increases faster than that of ordinary deep beams with the increase in a/d.

While part of the IR shown in Figure 4 and Table 3 may stem from the increasing efficiency of FRP with increasing a/d, the reduced strength of the $\mathrm{RC}$ beams with increasing a/d was another reason for the rise in IR. As shown in Table 3, the strength of non-strengthened RC beams declined significantly with increasing a/d, prompting an increase in IR values after strengthening. Therefore, part of the increase in IR was due to the increased efficiency provided by the FRP sheets.

In this study, the relationship between two significant ratios (IR and a/d) was considered in evaluating the behavior of CFRP-strengthened deep beams. Figure 4 illustrates the empirical relationship between the two ratios. This relationship served as the basis for STM modification to predict the shear strength of CFRP-strengthened deep beams. This issue is discussed in a separate section in this paper.

\subsection{Modified strut effectiveness factor for CFRP- strengthened deep beams}

STM was developed with an empirical equation to predict the ultimate shear strength of CFRPstrengthened deep beams in terms of the main CFRP properties such as thickness and modulus of elasticity. In this research, the strut effectiveness factor chosen for modification to accommodate CFRPstrengthened struts was the factor recommended by AASHTO LRFD over the ACI 318-11 proposal. This selection was considered because the strut 
TABLE 5. Ultimate shear strength of CFRP-strengthened deep beams,recommended method and empirical findings

\begin{tabular}{lcccc}
\hline ald & $\boldsymbol{\varepsilon}_{\mathbf{1}-\text { FRPrecommended }} \times \mathbf{1 0}^{-4}$ & $\boldsymbol{P}_{\boldsymbol{u} \text {-FRPrecommended }}(\boldsymbol{k} \boldsymbol{N})$ & $\boldsymbol{P}_{\boldsymbol{u} \text {-FRP-test }}(\boldsymbol{k N})$ & $\boldsymbol{P}_{\boldsymbol{u}-\boldsymbol{F R P r e c o m m e n d e d}}$ I $\boldsymbol{P}_{\boldsymbol{u}-\boldsymbol{F R} \boldsymbol{P} \text {-test }}$ \\
\hline 0.75 & 22.09 & 944.72 & 905.31 & 1.04 \\
1.00 & 40.08 & 801.66 & 857.89 & 0.93 \\
1.25 & 64.28 & 732.18 & 740.02 & 0.99 \\
1.50 & 94.47 & 634.65 & 691.04 & 0.92 \\
1.75 & 130.28 & 540.66 & 510.01 & 1.06 \\
2.00 & 171.26 & 459.95 & 468.05 & 0.98 \\
\hline
\end{tabular}

effectiveness factor recommended by AASHTO LRFD is calculated from the value of the principal tensile strain on the strut, which is measurable for the CFRP-strengthened struts used in the experiment. The principal tensile strain on struts was also measured to provide experimental support for verification, aside from the development of the strut effectiveness equation recommended by AASHTO LRFD for CFRP-strengthened deep beams.

The behavior of the CFRP-strengthened D-region was evaluated based on the principal tensile strain for bottle-shaped struts in STM. Based on Equation [5], the $\varepsilon_{1}$ for ordinary concrete struts was calculated from Equation [6] below.

$$
\varepsilon_{1}=0.005\left(\frac{f_{c r}}{f_{c 1}}-1\right)^{2}
$$

Equation [6] was derived from Equation [5] and developed for CFRP-strengthened concrete struts based on the contribution of the CFRP sheet. The compressive strength of concrete struts declined due to of concrete softening in response to the strut effectiveness factor in STM. The diagonal cracks along the strut centerline widened with the increase in the applied load. CFRP sheets prevented the diagonal cracks from widening compared to those diagonal cracks without CFRP-strengthening. This was

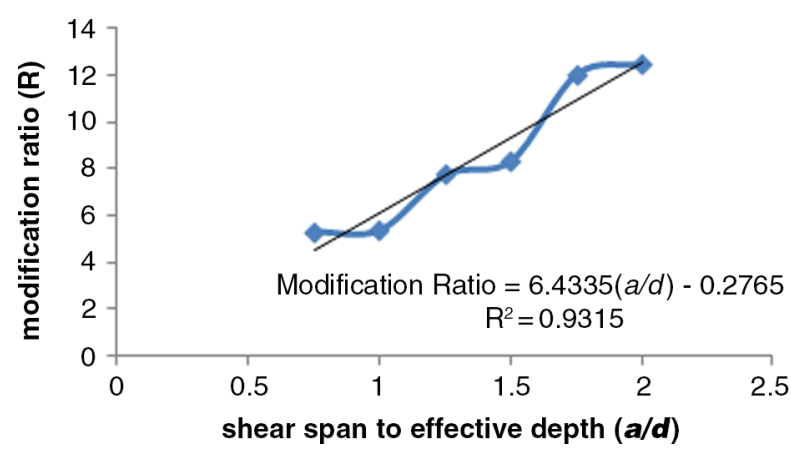

FIGURE 5. Principal tensile strain in CFRP-strengthened concrete struts, empirical relationship. because of the bond stress transferred to the concrete - CFRP interface.

Therefore, the principal tensile strain in CFRPstrengthened concrete struts in which the contribution of CFRP bonding stress is taken into consideration is proposed in Equation [7].

$$
\varepsilon_{1-F R P}=0.005\left(\frac{f_{c r}+\alpha \tau}{f_{c 1}+\beta \tau}-1\right)^{2}
$$

The contribution of CFRP bonding stress in Equation [7] varied for different shear span-to -effective depth ratios because of the non-linear behaviour of the D-region. This is the reason why reduction coefficients $\alpha$ and $\beta$ were used in Equation [7]. In order to calibrate Equation [7] with the experimental results, the values of reduction coefficients $\alpha$ and $\beta$ were assumed to be equal to 1.00 . Consequently, an empirical relationship was established in which reduction coefficients were used to attain the value of $\varepsilon_{1-F R P}$ as shown in Figure 5. This relationship was established as the ratio of $\varepsilon_{1-F R P}$ to $\varepsilon_{1-F R P-t e s t}$ as indicated in Table 4 . The principal tensile strain on both ordinary and CFRP-strengthened struts was measured with the DEMEC discs at the mid-height of the strut perpendicular to its centerline. $\varepsilon_{1-\text { ordinary-AASHTO }}$ and utilized as the basis of the calculation to attain $\varepsilon_{1-F R P}$. Based on the following empiri-

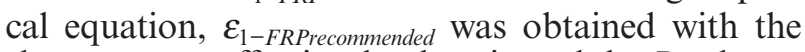
shear span-to-effective depth ratio and the $R$ value.

$$
R=6.4335\left(\frac{a}{d}\right)-0.2765
$$

Therefore,

$$
\varepsilon_{1-F R P r e c o m m e n d e d}=R \times \varepsilon_{1-F R P .}
$$

Using the a/d ratio, the modification ratio $(\mathrm{R})$ was calculated from Equation [8]. The value of $\varepsilon_{1-F R P}$ was calculated from Equation [7] since $\alpha$ and $\beta$ were equal to 1.00. Subsequently, $\varepsilon_{1-F R \text { Precommended }}$ was calculated from Equation [9]. The strut effectiveness factor for 
CFRP-strengthened RC deep beams was obtained from the value of $\varepsilon_{1-F R P r e c o m m e n d e d}$.

Table 5 provides a summary of the calculations and the recommended method and experimental ultimate shear strengths of CFRP-strengthened deep beams. Empirical Equation [9] gives the value of the principal tensile strain on CFRP-strengthened concrete struts.

\section{CONCLUSIONS}

This study investigated the application of the strut-and-tie model for CFRP-strengthened deep beams. It sought to establish an empirical relationship to modify the calculated value of the principal tensile strain on CFRP-strengthened struts. The following conclusions may be drawn.

1. An empirical relationship was established to modify the value of the strut effectiveness factor for CFRP-strengthened struts and to predict the value of principal tensile strain in struts for CFRP-strengthened deep beams.

2. The modified STM, which utilized the proposed empirical relationship, can be employed to predict the shear strength of CFRP-strengthened deep beams.

3. The experimental results showed that CFRPstrengthening increases the ultimate shear strength of deep beams from 19.60 to 30.02 with shear span-to-effective depth ratios of 0.75 to 2.00 , respectively.

4. The partial rupturing of the CFRP sheet is the dominant failure mode in two-sided CFRPstrengthened deep beams.

\section{ACKNOWLEDGMENTS}

The authors acknowledge the support from the Housing Research Center (HRC) and Dura Technology Company for facilitating the experimental work. Author a is deeply indebted to Taw Ly Wen, the English Instructor from University Putra Malaysia for her comments.

\section{SYMBOLS}

$a$ : shear span of deep beams $(\mathrm{mm})$

$d$ : effective depth of deep beam $(\mathrm{mm})$

$P_{u \text {-ordinary-test }}$ : ultimate shear strength of ordinary deep beam (empirical) $(k N)$

$P_{u \text {-FRP-test }}$ ultimate shear strength of CFRPstrengthened deep beam (empirical) $(k N)$

$P_{u-F R P \text {-recommended }}$ ultimate shear strength of CFRPstrengthened deep beam (proposed method) $(k N)$ $I R$ : increase ratio, ultimate shear strength of CFRPstrengthened deep beam to ultimate shear strength of ordinary deep beam

$R$ : modification ratio, ratio of $\varepsilon_{1-F R P-t e s t}$ to $\varepsilon_{1-F R P}$ $f_{c l}$ : principal tensile stress in concrete strut $(M P a)$ $f_{c r}$ : tensile stress of concrete (splitting test) ( $\left.M P a\right)$

$t$ : thickness of CFRP sheet $(\mathrm{mm})$

$E$ : Young's modulus for CFRP sheet $(M P a)$

$\mathrm{E}_{\mathrm{s}}$ : Young's modulus for steel bars $(M P a)$

$\varepsilon_{1}$ : principal tensile strain in concrete strut for ordinary deep beams $(\mathrm{mm} / \mathrm{mm})$

$\varepsilon_{s}$ : tensile strain in an adjoining tie $(\mathrm{mm} / \mathrm{mm})$

$\theta$ : angle between adjoining tie and strut $(\mathrm{rad})$

$f_{c}^{\prime}$ : specified concrete compressive strength $(M P a)$

$f_{c u}$ : effective compressive strength of concrete strut

(AASHTO LRFD) ( $M P a)$

$v$ : strut effectiveness factor

$\tau$ : average bond strength of concrete-CFRP $(M P a)$

$\varepsilon_{1-F R P}$ : principal tensile strain in CFRP-strengthened concrete strut (recommended equation before revision with empirical relationship) $(\mathrm{mm} / \mathrm{mm})$

$\alpha, \beta$ : reduction factors

$\varepsilon_{1-\text { ordinary-AASHTO }}$ principal tensile strain of ordinary concrete strut (AASHTO LRFD equation) $(\mathrm{mm} / \mathrm{mm})$

$\varepsilon_{1-F R P-t e s t}$ : principal tensile strain in CFRPstrengthened concrete strut (empirical) $(\mathrm{mm} / \mathrm{mm})$

$\varepsilon_{1-F R P-\text { recommended }}$ : principal tensile strain of CFRPstrengthened concrete strut (recommended equation after revision based on empirical relationship) $(\mathrm{mm} / \mathrm{mm})$

$\Delta_{\text {ordinary }}$ : mid-span deflection of ordinary RC deep beams $(\mathrm{mm})$

$\Delta_{\text {CFRP strengthening: mid-span deflection of CFRP- }}$ strengthened RC deep beams $(\mathrm{mm})$

\section{REFERENCES}

1. ACI (2011) Building Code Requirements for Structural Concrete and Commentary, section 10.7 and R10.7.

2. Kong, F.K. (1990) Reinforced Concrete Deep Beams. Blackie, Glasgow and London.

3. Wight, J.K.; Macgregor, J.G. (2009) Reinforced Concrete Mechanics and Design. Pearson Prentice Hall, United States.

4. Benachour, A.; Benyoucef, S.; Tounsi, A.; Adda bedia, E.A. (2008) Interfacial stress analysis of steel beams reinforced with bonded prestressed FRP plate. Engineering Structures. 30 [11], 3305-3315. http://dx.doi.org/10.1016/j.engstruct. 2008.05 .007 .

5. Jalali, M.; Sharbatdar, M.K.; Chen, J.-F.; Jandaghi Alaee, F. (2012) Shear strengthening of RC beams using innovative manually made NSM FRP bars. Construction and Building Materials. 36 [0], 990-1000. http://dx.doi.org/10.1016/j. conbuildmat.2012.06.068.

6. Panjehpour, M.; Farzadnia, N.; Anwar, M.P.; Ali1, A.A.A. (2011) FRP sheet contribution in common repair techniques of concrete structures with emphasis on concrete columns. International Journal of Sustainable Construction Engineering \& Technology. 2 [2], 54-61.

7. Panjehpour, M.; Rashid, R.S.M.; Aznieta, F.N.; Ali, A.A.A. (2012) A review for characterisation of FRP composite in the concrete structures. $11^{\text {th }}$ International Conference on Concrete Engineering and Technology 2012 (CONCET), Putrajaya, Malaysia, 12-13 June.

8. Rizzo, A.; De Lorenzis, L. (2009) Behavior and capacity of RC beams strengthened in shear with NSM FRP reinforcement. Construc. Build. Mat. 23 [4], 1555-1567. http:// dx.doi.org/10.1016/j.conbuildmat.2007.08.014.

9. Nardone, F.; Lignola, G.P.; Prota, A.; Manfredi, G.; Nanni, A. (2011) Modeling of flexural behavior of RC beams 
strengthened with mechanically fastened FRP strips. Composite Structures. 93 [8], 1973-1985. http://dx.doi. org/10.1016/j.compstruct.2011.03.003.

10. Rasheed, H.A.; Pervaiz, S. (2003) Closed form equations for FRP flexural strengthening design of RC beams. Composites Part B: Engineering. 34 [6], 539-550. http://dx.doi.org/ 10.1016/S1359-8368(03)00047-7.

11. Chen, G.M.; Teng, J.G.; Chen, J.F. (2012) Process of debonding in RC beams shear-strengthened with FRP U-strips or side strips. International Journal of Solids and Structures. 49 [10], 1266-1282. http://dx.doi.org/10.1016/j.ijsolstr.2012. 02.007 .

12. Godat, A.; Chaallal, O. (2012) Strut-and-tie method for externally bonded FRP shear-strengthened large-scale RC beams. Composite Structures. 99 [0], 327-338. http://dx.doi. org/10.1016/j.compstruct.2012.11.034.

13. Godat, A.; Chaallal, O.; Neale, K.W. (2012) Nonlinear finite element models for the embedded through-section FRP shear-strengthening method. Computers \& Structures.119 [0], 12-22. http://dx.doi.org/10.1016/j.compstruc.2012.12.016.

14. Godat, A.; Labossière, P.; Neale, K.W. (2012) Numerical investigation of the parameters influencing the behaviour of FRP shear-strengthened beams. Construc. Build. Mat. 32 [0], 90-98. http://dx.doi.org/10.1016/j.conbuildmat. 2010.11.110.

15. Godat, A.; Labossière, P.; Neale, K.W.; Chaallal, O. (2012) Behavior of RC members strengthened in shear with EB FRP: Assessment of models and FE simulation approaches. Computers \& Structures. 92-93 [0], 269-282.

16. Nasrollahzadeh, K.; Basiri, M.M.(2014) Prediction of shear strength of FRP reinforced concrete beams using fuzzy inference system. Expert Systems with Applications. 41 [4], 1006-1020. http://dx.doi.org/10.1016/j.eswa.2013.07.045.

17. Pellegrino, C.; Vasic, M. (2013) Assessment of design proceduresfor theuse of externallybondedFRPcompositesinshear strengthening of reinforced concrete beams. Composites Part B: Engineering. 45 [1], 727-741. http://dx.doi.org/10.1016/j. compositesb.2012.07.039.

18. Perera, R.; Ruiz, A. (2012) Design equations for reinforced concrete members strengthened in shear with external FRP reinforcement formulated in an evolutionary multi-objective framework. Composites Part B: Engineering. 43 [2], 488-496. http://dx.doi.org/10.1016/j.compositesb.2011.10.013.

19. Perera, R.; Vique, J.; Arteaga, A.; Diego, A.D. (2009) Shear capacity of reinforced concrete members strengthened in shear with FRP by using strut-and-tie models and genetic algorithms. Composites Part B: Engineering. 40 [8], 714-726. http://dx.doi.org/10.1016/j.compositesb.2009.06.008.

20. El Maaddawy, T.; Sherif, S. (2009) FRP composites for shear strengthening of reinforced concrete deep beams with openings. Composite Structures. 89 [1], 60-69. http://dx.doi. org/10.1016/j.compstruct.2008.06.022.

21. Hawileh, R.A.; El-Maaddawy, T.A.; Naser, M.Z.(2012) Nonlinear finite element modeling of concrete deep beams with openings strengthened with externally-bonded composites. Materials \& Design. 42 [0], 378-387. http://dx.doi. org/10.1016/j.matdes.2012.06.004.

22. Lee, H.K.; Cheong, S.H.; Ha, S.K.; Lee, C.G. (2011) Behavior and performance of RC T-section deep beams externally strengthenedinshearwithCFRPsheets. CompositeStructures. 93 [2],911-922. http://dx.doi.org/10.1016/j.compstruct.2010. 07.002 .

23. Abdalla, J.A.; Hawileh, R.; Al-Tamimi, A. (2011) Prediction of FRP-concrete ultimate bond strength using Artificial Neural Network. Paper presented at the Modeling, Simulation and Applied Optimization (ICMSAO), 4th International Conference on Kuala lumpur, 19-21.

24. Lu, X.Z.; Teng, J.G.; Ye, L.P.; Jiang, J.J. (2005) Bondslip models for FRP sheets/plates bonded to concrete. Engineering Structures. 27 [6], 920-937. http://dx.doi.org/ 10.1016/j.engstruct.2005.01.014.

25. Mashrei,M.A.;Seracino, R.;Rahman,M.S.(2013)Application of artificial neural networks to predict the bond strength of FRP-to-concrete joints. Construc. Build. Mat. 40, 812-821. http://dx.doi.org/10.1016/j.conbuildmat.2012.11.109.

26. Seo, S.-Y.; Feo, L.; Hui, D. (2013) Bond strength of near surface-mounted FRP plate for retrofit of concrete structures. Composite Structures. 95 [0], 719-727. http:// dx.doi.org/10.1016/j.compstruct.2012.08.038

27. Tighiouart, B.; Benmokrane, B.; Mukhopadhyaya, P. (1999) Bond strength of glass FRP rebar splices in beams under static loading. Construc. Build. Mat. 13 [7], 383-392. http:// dx.doi.org/10.1016/S0950-0618(99)00037-9.

28. Tuakta, C.; Büyüköztürk, O.; M.ASCE. (2011) Conceptual model for prediction of FRP-concrete bond strength under moisture cycles. Ournal of composites for construction (ASCE). 2 [1]

29. De Lorenzis, L.; Miller, B.; Nanni, A. (2001) Bond of FRP laminates to concrete. ACI Materials Journal. 98 [3], 256-264.

30. AASHTO: LRFD, bridge design specifications, customary U.S. units: 2008 interim revisions, 4 ed. American Association of State Highway and Transportation Officials, Washington.

31. AS3600 (2009) Australian standard for Concrete structures. In., p. 198. standard association of Australia, North sydney.

32. Béton, F.I.d.: Model Code 2010. vol. v. 1. International Federation for Structural Concrete (fib).

33. CAN/CSA-S6-06 (2006) Canadian highway bridge design code and S6.1-06 commentary on CAN/CSA-S6-06, Canadian Highway Bridge Design Code. Association canadienne de normalisation.

34. CSA-A23.3-04 (2005) Technical Committee on Reinforced Concrete Design. A23.3-04 Design of Concrete Structures. Canadian Standards Association.

35. DIN: Building and Civil Engineering Standards Committee (2001) Plain, Reinforced and Prestressed Concrete Structures, Part 1: Design and Construction (DIN 1045-1). Deutsches Institut für Normung (DIN-Normen), Berlin, Germany.

36. NZS (2006) Concrete Design Committee P 3101 for the Standards Council. Concrete Structures Standard: Part 1-The Design of Concrete Structures (NZS 3101-1). Standards New Zealand, Wellington.

37. Vecchio, F.J.; Collins, M.P. (1986) The modified compressionfield theory for reinforced concrete elements subjected to shear, Title no. 83-22. ACI Journal.

38. Panjehpour, M.; Ali, A.A.A.; Anwar, M.P.; Aznieta, F.N.; Voo, Y.L. (2012) An overview of strut-and-tie model and its common challenges. International journal of engineering research in Africa 8, 37-45

39. Panjehpour, M.; Ali, A.A.A.; Voo, Y.L.; Aznieta, F.N (2012) Strut elaboration in strut-and-tie model. ConstructII $2,45-53$

40. Bruggi, M. (2009) Generating strut-and-tie patterns for reinforced concrete structures using topology optimization. Computers \&amp; Structures. 87 [23-24], 1483-1495. http:// dx.doi.org/10.1016/j.compstruc.2009.06.003.

41. He, Z.-Q.; Liu, Z. (2010) Optimal three-dimensional strutand-tie models for anchorage diaphragms in externally prestressed bridges. Engineering Structures. 32 [8], 20572064. http://dx.doi.org/10.1016/j.engstruct.2010.03.006.

42. Khalifa, E.S. (2010) Macro-mechanical strut and tie model for analysis of fibrous high-strength concrete corbels. Ain Shams Engineering Journal. 3 [4], 359-365. http://dx.doi. org/10.1016/j asej.2012.04.004

43. Kwak, H.-G.; Noh, S.-H. (2006) Determination of strutand-tie models using evolutionary structural optimization. Engineering Structures. 28 [10], 1440-1449. http://dx.doi.org/ 10.1016/j.engstruct.2006.01.013

44. Perera, R.; Vique, J. (2009) Strut-and-tie modelling of reinforced concrete beams using geneticalgorithmsoptimization. Construc. Build. Mat. 23 [8], 2914-2925. http://dx.doi.org/ 10.1016/j.conbuildmat.2009.02.016.

45. Tjhin, T.N.; Kuchma, D.A. (2007) Integrated analysis and design tool for the strut-and-tie method. Engineering Structures. 29 [11], 3042-3052. http://dx.doi.org/10.1016/j. engstruct.2007.01.032.

46. Wang, G.-L.; Meng, S.-P. (2008) Modified strut-and-tie model for prestressed concrete deep beams. Engineering Structures. 30 [12], 3489-3496. http://dx.doi.org/10.1016/j. engstruct.2008.05.020.

47. Zhang, N., Tan, K.-H. (2007) Size effect in RC deep beams: Experimental investigation and STM verification. Engineering Structures. 29 [12],3241-3254.http://dx.doi.org/ 10.1016/j.engstruct.2007.10.005. 